\title{
A Case of Fatal Congenital Human Immunodeficiency Virus Infection
}

\section{Fatal Seyirli Bir Konjenital Insan Immün Yetmezlik Virüsü Enfeksiyonu Olgusu}

\author{
Halil Uğur Hatipoğlu, Murat Elevli*, Ayşe Bahar Budan Çalışkan**, \\ Hatice Nilgün Selçuk Duru, Mahmut Çivilibal, Ali Karakuş \\ Haseki Training and Research Hospital, Clinic of Pediatrics, istanbul, Turkey \\ *Sakarya University Faculty of Medicine, Department of Pediatrics, Sakarya, Turkey \\ **Haseki Training and Research Hospital, Clinic of Pediatrics, Pediatric Infectious Diseases Unit, Istanbul, Turkey
}

\begin{abstract}
Acquired immune deficiency syndrome is a clinical condition caused by human immunodeficiency virus (HIV) which can be transmitted either vertically or horizontally. More than $90 \%$ of children living with HIV in developing countries have been infected through mother to child transmission during pregnancy, around the time of birth, or through breastfeeding. In order to reduce the number of infected children, increasing emphasis should be placed on preventing mother to child transmission programs with the use of antiretroviral medications in the pregnant woman during pregnancy and at delivery and, starting immediately after birth for the exposed infant. Here, we present the case of a 60-day-old infant heavily immunocompromised due to an extremely high viral burden of HIV, which was acquired perinatally from an undiagnosed and untreated mother, leading to severe bronchopneumonia, sepsis, septic shock and death.
\end{abstract}

Keywords: Acquired immune deficiency syndrome, mother-to-child transmission, immunocompromised
Öz

Edinsel bağışıklık yetmezliği sendromu vertikal veya horizontal olarak bulaşabilen insan immun yetmezlik virüsünün (HIV) neden olduğu bir klinik tablodur. Gelişmekte olan ülkelerde HiV ile enfekte çocukların \%90'ından fazlası bu virüse gebelik boyunca, doğum esnasında ya da emzirmeyle anneden bebeğe bulaş yoluyla maruz kalmış olan çocuklardır. Enfekte çocuk sayısını azaltmak için antiretroviral ilaç tedavilerinin enfekte gebelerde gebelik boyunca ve doğum esnasında kullanımı, risk alındaki bebeklerde de doğar doğmaz başlanması suretiyle anneden-bebeğe-bulaş önleyici programların üstünde daha fazla durulmalıdır. Bu olguda; tanı almamış ve tedavi olmamış bir annenin perinatal dönemde enfekte olan, aşırı derecede yüksek Hiv viral yüküne bağlı olarak ağır immün yetmezlik gelişen ve bunun sonucunda ciddi bronkopnömoni, sepsis, ve septik şok nedeniyle eksitus olan 60 günlük bebeği sunulmaktadır.

Anahtar Sözcükler: Edinsel bağışıklık yetmezliği sendromu, anneden bebeğe bulaş, immünitesi zayıflamış

\section{Introduction}

Acquired immune deficiency syndrome (AIDS) is a clinical condition caused by human immunodeficiency virus (HIV) which can be transmitted either vertically or horizontally. Vertical transmission from mother to child, predominantly seen in perinatal period, is responsible for $70-95 \%$ of the pediatric cases $(1,2)$. Timing of HIV transmission from mother to child seems to be an important determinant of disease progression. The infection may be acquired either via transplacental transmission in antenatal period or during delivery, by contamination of fetal circulation with mother's blood or as a result of contact with blood, and secretions of infected mother. Breast-feeding, another route of transmission, might play a significant role (16.2\%) in transmission in the postnatal period (3). Preterm delivery, low birth weight (less than 2.500 grams), mother with advanced-stage disease (low $\mathrm{CD}_{4}$ level, high viral load), vaginal delivery, invasive procedures such as episiotomy,
Address for Correspondence/Yazışma Adresi: Halil Uğur Hatipoğlu Haseki Training and Research Hospital, Clinic of Pediatrics, İstanbul, Turkey Phone.: +90212533 3461 E-mail: huhatipoglu@gmail.com Received/Geliş Tarihi: 28 November 2015 Accepted/Kabul Tarihi: 07 December 2015
The Medical Bulletin of Haseki Training and Research Hospital, published by Galenos Publishing.

Haseki Tıp Bülteni, Galenos Yayınevi tarafından basılmıştır. 
prolonged delivery, premature rupture of membranes, chorioamnionitis, mastitis, cracked or bleeding nipples are some of the risk factors that can increase transmission from mother to her sibling (2-6).

Among children, especially in those who have acquired the infection vertically, there is considerable variability in the presenting manifestations of HIV infection, progression of the disease, immunosuppression, and mortality depending on the time of transmission. Some of the major symptoms of pediatric AIDS include lymphadenopathy, splenomegaly, growth retardation, failure to thrive, recurrent infections, cardiomyopathy, hepatitis, nephropathy, and neuropathy (1). Here, we report a 60-day-old infant girl immunocompromised due to an extremely high viral burden of HIV, which was acquired perinatally, leading to severe bronchopneumonia, sepsis, septic shock and death.

\section{Case}

A 60-day-old girl was admitted to our intensive care unit (ICU) with a significant respiratory distress which had started while being treated at another hospital with the diagnosis of bronchopneumonia, aphthous ulcers in the mouth and diarrhea. She was born at 39th gestational week by caesarean section, weighing 4.060 grams from a 32-year-old Moroccan mother. At birth, she was in well condition and her physical examination was unremarkable. She was initially breastfed which was discontinued a few days later for the mother got cracked and sore nipples. Her mother noticed thrush on the third day after birth which progressively worsened in two months. She could only gain 300 grams/month since birth, started coughing a week before and had fever $\left(38.5^{\circ} \mathrm{C}\right)$ and diarrhea a day before her previous hospitalization which was three days before our ICU admission. On admission to ICU, she had crepitant rales widespread on both lung areas, $2 \mathrm{~cm}$ of splenomegaly, $3 \mathrm{~cm}$ of hepatomegaly, and severe candida infection in oral mucosa. The remaining of physical examination was unremarkable. Her body temperature was $39.2{ }^{\circ} \mathrm{C}$, blood pressure-70/35 $\mathrm{mmHg}$ and heart rate was 180 beats per minute. Ampicillin-sulbactam and cefotaxime which were initiated during her previous hospital stay was changed to teikoplanin-meropenem. Fluconasole was added to the therapy. She had severe respiratory distress; chest $x$-ray showed patchy infiltration bilaterally, predominantly scattered around mediastinum (Figure 1). Analysis of venous blood gas revealed respiratory acidosis $(\mathrm{pH}: 7.21$, $\mathrm{pCO}_{2}$ : 76.3) and hypoxemia which led to mechanical ventilation. Peripheral blood showed a leukocyte count

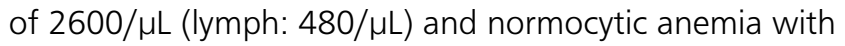
a hemoglobin level of $9.6 \mathrm{~g} / \mathrm{dL}$. The blood chemistry was normal except low total protein and albumin levels which were $4.2 \mathrm{~g} / \mathrm{dL}$ and $2.05 \mathrm{~g} / \mathrm{dL}$, respectively. C-reactive protein was also within the normal limits. On the second day of ICU admission, an erythematous plaque-like skin eruption developed on the trunk and limbs (Figure 2). Considering severe infection along with lymphopenia, an ELISA test for HIV Ab was performed which gave a positive result. The mother was also tested for HIV and found to be positive too. The result was confirmed by the Western blot method. She did not get a proper medical care during her pregnancy, nor did she know that she had been infected. Thus, she was not given any treatment for HIV during her pregnancy and birth. The patient was considered to be infected vertically as she did not have a history of blood transfusion or any other contact with any infected material. Immune profiling of the patient revealed a total lymphocyte count of $240 / \mu \mathrm{L}$ with a $\mathrm{CD}_{4}$ level of $72 / \mu \mathrm{L}(30 \%), \mathrm{CD}_{8}$ level of $120 / \mu \mathrm{L}(50 \%) . \mathrm{CD}_{4} /$ $\mathrm{CD}_{8}$ ratio was 0.6. A blood sample for viral load (HIV1 RNA) detection with the polymerase chain reaction (PCR) method revealed 8.9 million copies $/ \mathrm{mL}$. The patient was immediately put on lamivudine, zidovudine and lopinavir/ritonavir [highly active antiretroviral therapy; (HAART)] therapy on the 14th day of her hospitalization. She was evaluated to be in the advanced stage of HIV as she had a significantly high viral burden and a low percentage of $\mathrm{CD}_{4}$ T-cell ( $<15 \%$; immunologic category: 3). Trimethoprime-sulfamethoxazole was started because of presumed Pneumocystis carinii pneumonia. The skin

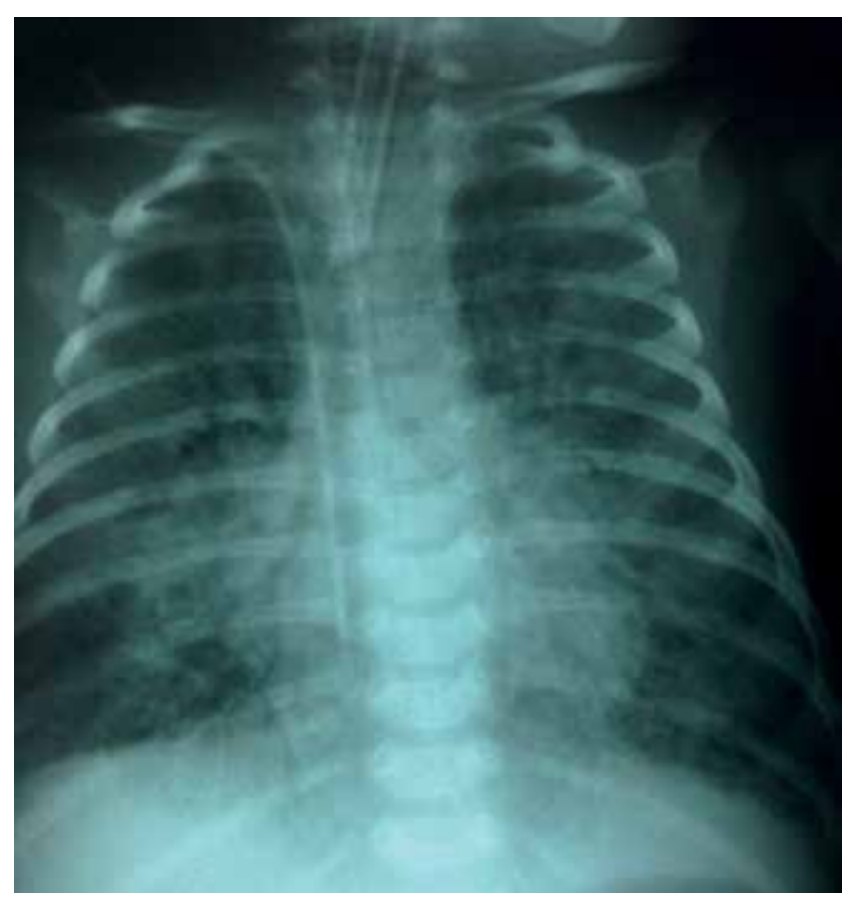

Figure 1. Bilateral patchy infiltration, predominantly scattered around mediastinum 
eruption completely regressed on the $4^{\text {th }}$ day of HAART treatment (Figure 3). Blood, tracheal aspiration, urine and stool cultures were all negative for any pathogen microorganism. Immunoglobulin levels (Ig A: $10.02 \mathrm{mg} /$ dL, IgG: $467.89 \mathrm{mg} / \mathrm{dL}$, IgM: $43.00 \mathrm{mg} / \mathrm{dL}$ ) were normal for the age-matched range. Chest $x$-ray on the $10^{\text {th }}$ day of antiretroviral (ARV) treatment showed a significant improvement. Five days later, on the 29th day of ICU admission, the patient's clinical and laboratory status suddenly got worse. She was still being ventilated when a respiratory and metabolic acidosis developed. She became hypotensive and febrile again. Diffuse bilateral ground glass opacities were evident on chest x-ray (Figure 4). Blood analysis revealed elevated liver enzymes (AST: $2840.30 \mathrm{U} / \mathrm{L}$, ALT: $682.73 \mathrm{U} / \mathrm{L})$, a high level of LDH $(4383.76 \mathrm{U} / \mathrm{L})$ and low levels of total protein $(3.59 \mathrm{gr} / \mathrm{dL})$ and albumin $(1.94 \mathrm{~g} / \mathrm{dL})$. Complete blood count showed

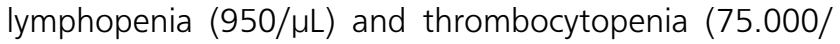
$\mu \mathrm{L})$. Coagulation tests were severely impaired along with a D-dimer level of $5171 \mathrm{ng} / \mathrm{mL}$. She was diagnosed as having sepsis, acute respiratory distress syndrome, septic shock, and disseminated intravascular coagulopathy. Despite the appropriate medical approach and supportive

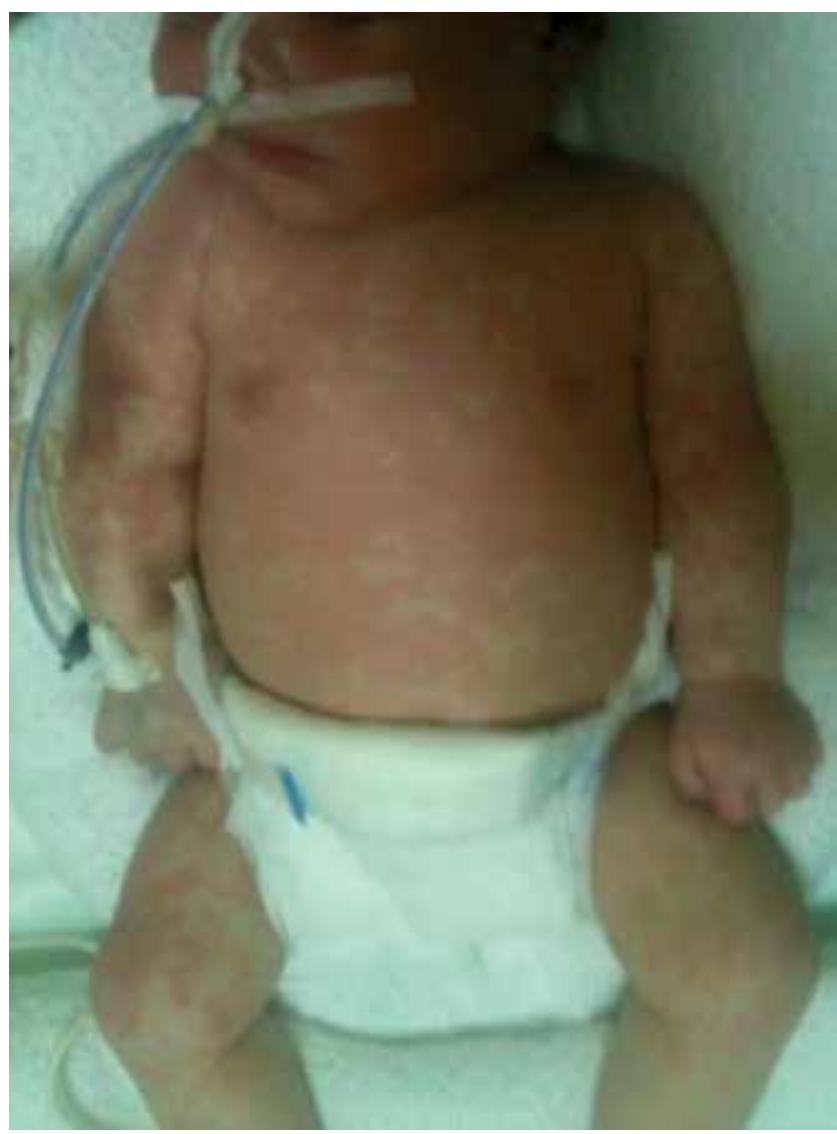

Figure 2. Erythematous-plaque like skin eruption on the trunk and limbs therapy, the patient's medical condition worsened and mucosal bleeding started. She did not respond to resuscitation given for the cardiopulmonary arrest on the 32 nd day of her hospitalization and eventually died.

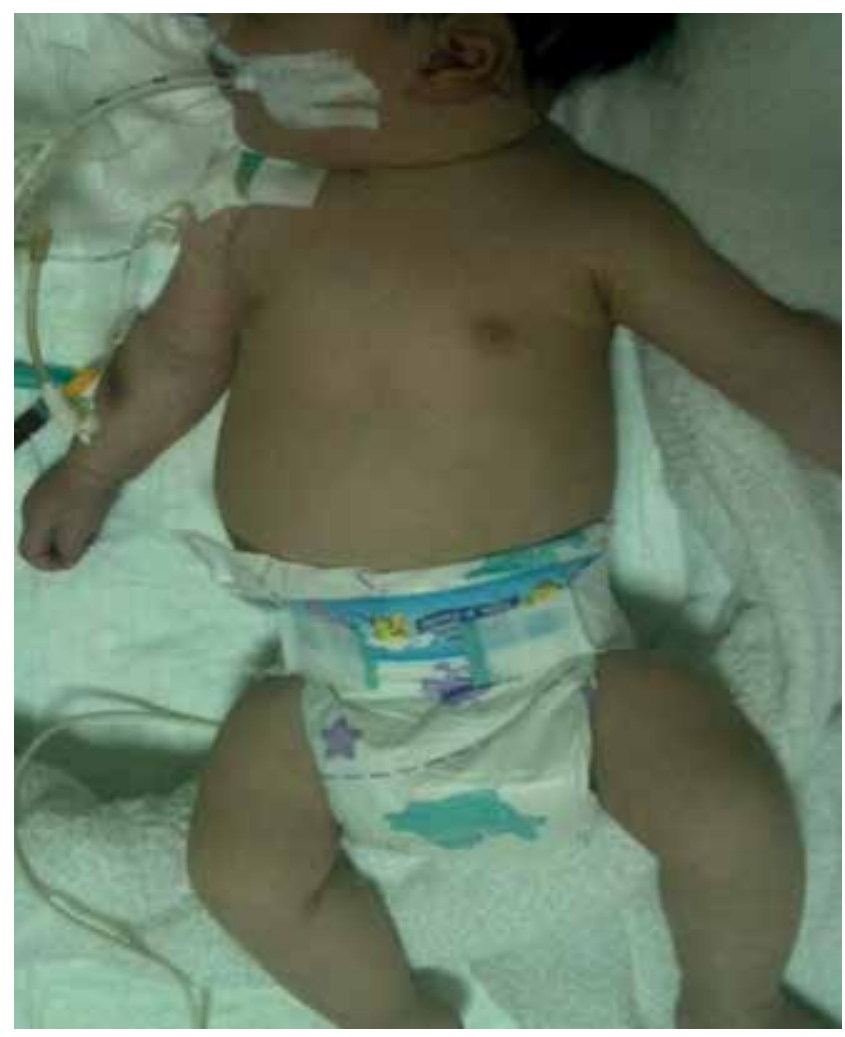

Figure 3. Regressed skin eruption on the $4^{\text {th }}$ day of highly active antiretroviral therapy treatment

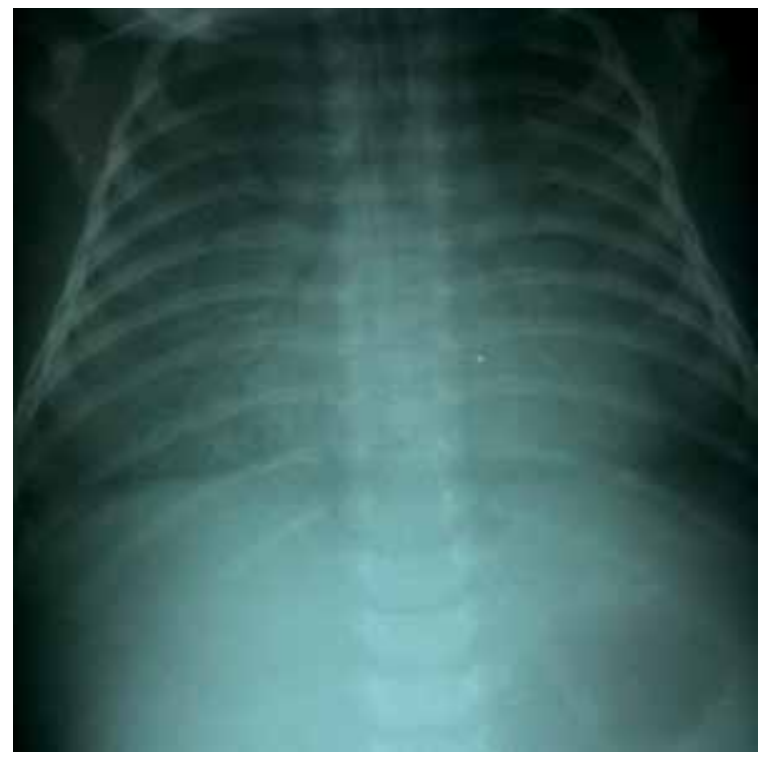

Figure 4. Diffuse bilateral ground glass opacities were evident on chest x-ray 


\section{Discussion}

In more than $90 \%$ of all new pediatric HIV cases, the cause of infection is perinatal transmission of HIV that can occur during pregnancy (in utero) at labor/delivery (intrapartum), or post-delivery (postnatal) through breastfeeding. In non-breastfeeding settings before the availability of ARV treatment, in utero infections (demonstrated by a positive HIV RNA PCR test in the infant within three days after birth) accounted for about one-third of the infant HIV infections, while about twothirds of transmissions occurred around the time of labor and delivery (demonstrated by a positive HIV RNA $P C R$ test in the infant that was negative within the first three days after birth, but then positive by four to six weeks of age) (7). In breastfeeding settings before the availability of ARV treatment, about $25-40 \%$ of infant infections were supposed to occur in utero, about 50\% around the time of labor/delivery or through very early breastfeeding, and the rest during the breastfeeding period (8). Unfortunately, the mother of our patient had not been screened for and diagnosed with HIV during her pregnancy. Therefore, her baby did not have a chance to be tested for HIV in the first 72 hours of her life until she was hospitalized with a severe infection two months later. We assume that if she could have been screened in the first theree days, she would probably have been diagnosed to have HIV as she had a very high level of viral load when she was two months old indicating a possible intrauterine transmission. In our case, the mother was asymptomatic, but viral load could not be evaluated because of her socioeconomic status.

A majority of in utero transmission is supposed to occur throughout the third trimester. This opinion is based on lower rates of viral detection on fetal tissue from abortions in the first and second trimester rather than the third trimester (9). In a study of long versus short antenatal zidovudine prophylaxis for prevention of mother to child transmission, the rate of in utero transmission was $5.1 \%$ when starting zidovudine at the $36^{\text {th }}$ week of gestation compared with $1.6 \%$ when starting zidovudine at the $28^{\text {th }}$ week of gestation. This suggests that a significant proportion of transmission may occur between 28 to 36 weeks of gestation, and a smaller residual amount of in utero infection may occur earlier in pregnancy (10). Mechanisms of transmission are estimated to be related to breakdown of the completeness of the placenta, leading to microtransfusions of viremic maternal blood across the placenta to the fetus (11). In a number of studies, it has been shown that placental inflammation and genital tract infections, especially chorioamnionitis, can increase in utero HIV transmission (12). Intrapartum transmission is postulated to occur through contact of infant mucosal membranes with HIV virus in secretions and blood during the birth process. In the absence of ARV treatment, increased risk of transmission has been associated with duration of membrane rupture greater than four hours (13). In addition, microtransfusions across the placenta during labor contractions also probably conduce to the increased risk of transmission during the labor and delivery period (11). Transmission during breastfeeding is predominantly related to the intake of infected milk and blood from cracked and bleeding nipples. Our patient could only be breastfed for a few days after birth because of the mother's discomfort due to cracked nipples which disabled her to breastfeed her infant. This might have caused perinatal transmission, but considering the extreme amount of viral load detected in this two-month-old patient, it is quite reasonable to think that our patient was more likely to have acquired the infection in utero.

Most untreated HIV-infected children show progression of HIV infection to AIDS and die before reaching age five years $(14,15)$. Among children, especially in those who acquired the infection vertically, there is considerable variability in the presenting manifestations of HIV infection, progression of disease, immunosuppression, and mortality. Children appear to follow two basic patterns in the progression of untreated infection: a rapid progression of the disease in which children reach severe clinical and/or immunologic stages within the first year of life, or a more typical, slower progression, with clinical and immunologic deterioration by five to six years of life. Timing of HIV transmission from mother to child seems to be an important determinant of disease progression. Children infected in utero or within the first one to two months of life have a higher mortality rate at 12 months than those infected later $(15,16)$. In our case, the symptoms progressed in a very short time like 60 days and AIDS developed rapidly indicating a possible intrauterine transmission.

According to the global summary of the AIDS epidemic in 2013 announced by World Health Organization, the number of children ( $<15$ years) living with HIV is 3.2 million, whereas the number of children ( $<15$ years) newly infected with HIV is 240.000 and the number of deaths due to AIDS for this population is 190.000 (17). In our country, the Ministry of Health reported the number of living children (<19 years) with HIV as 209 in June 2013, and the total number of infected people as 6800 (4).

The use of ARV agents by pregnant women and their children is a critical component of prevention of mother to child transmission (MTCT) during the antepartum and peripartum periods as well as throughout the duration 
of breastfeeding. In perinatal studies, the use of ARV interventions has been shown to be the most important factor for reducing the risk of MTCT, overriding clinical, virologic, and immunologic risk factors. Cesarean delivery decreases the transmission rate by $50 \%$, and perinatal zidovudin administration to the mother and the baby decreases the transmission rate by $87 \%(3,6)$. Our patient was born with cesarean delivery but no ARV agent was used to prevent MTCT since the mother had not been followed by a doctor during pregnancy and her HIV status was unknown. In order to reduce the number of infected children, increasing emphasis should be placed on preventing MTCT with the use of ARV medications in the pregnant woman during pregnancy and at delivery and starting immediately after birth for the exposed infant. Immunocompromised states, especially vertically transmitted HIV infection should always be kept in mind when evaluating a newborn or an infant with severe infections as in our case.

\section{Conclusion}

This case is being reported to emphasize perinatally acquired HIV infection posing a distinctive place in immunocompromised states seen in early infancy and the importance of using ARV agents by pregnant women and their children to prevent MTCT during the antepartum and peripartum periods. In addition, the rarity of such an extreme amount of viral load detected in a very young infant indicating a possible early perinatal transmission is another bullet point of our presentation. Awareness of this rare clinical entity prevents delays in the initiation of HAART.

\section{Ethics}

Informed Consent: It was taken a written informed consent from the patient's parent on the medical informations about the patient and his parents and the visuals belongs to the patient could be used in scientific studies on condition that undisclose his credentials and his face would not be seen in the images.

Peer-review: Internal peer-reviewed.

\section{Authorship Contributions}

Surgical and Medical Practices: Murat Elevli, Halil Uğur Hatipoğlu, Ali Karakuş. Concept: Halil Uğur Hatipoğlu, Ayşe Bahar Budan Çalışkan, Murat Elevli, Mahmut Çivilibal. Design: Ayşe Bahar Budan Çalışkan, Halil Uğur Hatipoğlu, Murat Elevli, Hatice Nilgün Selçuk Duru. Data Collection or Processing: Halil Uğur Hatipoğlu, Ayşe Bahar Budan Çalışkan, Ali Karakuş. Analysis or Interpretation: Halil Uğur Hatipoğlu, Ayşe Bahar Budan Çalışkan, Murat Elevli.
Literature Search: Halil Uğur Hatipoğlu, Ayşe Bahar Budan Çalışkan. Writing: Halil Uğur Hatipoğlu.

Conflict of Interest: No conflict of interest was declared by the authors.

Financial Disclosure: The authors declared that this study has received no financial support.

\section{References}

1. Jennifer $\mathbf{S}$. Read. Human Immuno deficiency virus and the acquired immunodeficiency syndrome. In: Long SS, Pickering $L K$, Prober CG, editors. Principles and practice of pediatric infectious diseases. 4th ed. New York: Saunders; 2012. p.1308-17.

2. Ibeziako NS, Ubesie AC, Emodi IJ, Ayuk AC, Iloh KK, Ikefuna AN. Mother-to-child transmission of HIV: the pre-rapid advice experience of the university of Nigeria teaching hospital Ituku/Ozalla, Enugu, South-east Nigeria. BMC Research Notes 2012;5:305.

3. Özkaya Parlakay A, Kara A, Cengiz AB, Çelik M, Ceyhan M. Perinatal HIV and prophylaxis: case reports. Türk Ped Ars 2012;47:59-62.

4. Türkiye Cumhuriyeti Sağılık Bakanlığı HIV/AIDS veri tabloları 2013. Avaible from URL:http://www.hatam.hacettepe.edu. tr/veriler_Haziran_2013.pdf. Downloaded August 10, 2014.

5. Dalgıç N. Congenital human ımmunodeficiency Virus (HIV) Infection. Ankara Üniversitesi Tıp Fakültesi Mecmuası 2007;60:1-6.

6. Yogev R, Chadwick EG. Acquired immuno deficiency syndrome (Human immuno deficiency virus). In: Kliegman RM, Stanton BF, St. Geme JW, Schor NF, Behrman RE, editors. Nelson Textbook of Pediatrics, 19th ed. Philadelphia: Saunders; 2011. p. 1157-77.

7. Mofenson LM. Mother-child HIV-1 transmission: Timing and determinants. Obstet Gynecol Clin North Am 1997;24:75984.

8. De Cock KM, Fowler MG, Mercier E, et al. Prevention of mother-to-child HIV transmission in resource-poor countries: translating research into policy and practice. JAMA 2000;283:1175-82.

9. Ehrnst A, Lindgren S, Dictor M, et al. HIV in pregnant women and their offspring: evidence for late transmission. Lancet 1991;338:203-7.

10. Lallemant $M$, Jourdain $G$, Le Coeur $S$, et al. A trial of shortened zidovudine regimens to prevent mother-to-child transmission of human immunodeficiency virus type 1 . Perinatal HIV Prevention Trial (Thailand) Investigators. N Engl J Med 2000;343:982-91.

11. Kourtis AP, Bulterys M, Nesheim SR, Lee FK. Understanding the timing of HIV transmission from mother to infant. JAMA 2001;285:709-12.

12. King CC, Ellington SR, Kourtis AP. The role of co-infections in mother-to-child transmission of HIV. Curr HIV Res 2013;11:1023.

13. Landesman SH, Kalish LA, Burns DN, et al. Obstetrical factors and the transmission of human immunodeficiency virus type 
1 from mother to child. The Women and Infants Transmission Study. N Engl J Med 1996;334:1617-23.

14. Spira R, Lepage $P$, Msellati $P$, et al. Natural history of human immunodeficiency virus type 1 infection in children: a five-year prospective study in Rwanda. Mother-to-Child HIV-1 Transmission Study Group. Pediatrics 1999;104:56.

15. Newell ML, Coovadia H, Cortina-Borja M, et al. Mortality of infected and uninfected infants born to HIV-infected mothers in Africa: a pooled analysis. Lancet 2004;364:1236-43.

16. Mbori-Ngacha D, Nduati R, John G, et al. Morbidity and mortality in breastfed and formula-fed infants of HIV-1-infected women: A randomized clinical trial. JAMA 2001;286:2413-20.

17. Dünya Sağlık Örgütü HIV/AIDS verileri 2013. Avaible from:s URL:http://www.who.int/hiv/data/epi_core_dec2014. png?ua=1. Downloaded August 10, 2014. 